\title{
The Role of Microcredit Activities as an Instrument for Poverty Reduction: An Analysis from Mozambique
}

\author{
Jochua Abrão Baloi \\ Faculty of Ethics, Human and Legal Sciences of the University of Saint Thomas of Mozambique, Maputo, Mozambique \\ Email address: \\ jbaloi@yahoo.com.br \\ To cite this article: \\ Jochua Abrão Baloi. The Role of Microcredit Activities as an Instrument for Poverty Reduction: An Analysis from Mozambique. \\ International Journal of Finance and Banking Research. Vol. 5, No. 3, 2019, pp. 36-47. doi: 10.11648/j.ijfbr.20190503.11
}

Received: April 28, 2019; Accepted: June 3, 2019; Published: July 1, 2019

\begin{abstract}
This article comes about with the objective of analyzing the role of microcredit activities as a tool for poverty reduction in Mozambique, and specifically to sellers of the Xipamanine Market in Maputo City. The central thesis to be defended is that: microcredit if is well managed contributes to improve the socioeconomic conditions of populations that do not have access to credit in traditional banks. The research was carried out in Xipamanine Market in Maputo City and the data collection on the survey was carried out based on interviews with the sellers of this market. In general, about $90 \%$ of the respondents indicated that, in fact, whenever banks grant microcredit to borrowers and they manage it well, there is a change in their initial situation. According to the respondents, the traditional financial system leads to exclusion of certain categories such as low-income populations and especially the poorest people. Therefore, this article draws the conclusion that microcredit has a significant impact on the Mozambican economy, since, in addition to being able to generate individual wealth, it contributes significantly as an instrument to fight against poverty.
\end{abstract}

Keywords: Credit, Microfinance, Poverty, Mozambique

\section{Introduction}

This article analyzes the role of microcredit activities as an instrument for poverty reduction, taking as a case study the Xipamanine Market in Maputo City. The choice of this topic was because, the functioning of the Mozambican financial system leads to exclusion, certain categories, such as the lowincome population due to lack of financial resources and / or real guarantees. Therefore, the difficulty of being financed is increasing, and microcredit is an element of great relevance in the productive dynamics of the country, mainly due to its target audience, this layer of low income.

The choice of Xipamanine Market is because, it is a place where there is a greater concentration of informal sellers who have a low income and scarce financial resources, which leads many of them to join microcredit as a way to monetize their sale.

Thus, faced with this difficulty of access to credit by the poor population, this research presents microcredit as a strong instrument capable of contributing to the creation and growth of micro and small enterprises, in order to improve the living conditions of the poor population, fighting and reducing the rate of extreme poverty in Mozambique.

The issue of low-income population access to financial services or activities has been singled out as a major problem in academia and within public policies in recent years for poverty reduction. According to (Firmino, 2017: 13), "Microcredit is the term used to refer to small-value loans, whose limits vary from country to country. This type of credit is aimed at a restricted, defined by people of low income or who do not have access to the forms traditional credit systems. Microcredit aims to support entrepreneurship and the creation of employment, through loans to people who cannot obtain another kind of credit institutions because of their low indebtedness". In this perspective, Microcredit is a credit destined to the production of goods and services with the purpose of generating income and is granted according to specific norms established by the bank to grant the credit.

Still in this perspective, Dantas (2014) asserts that Microcredit is necessarily in the context of microfinance, which is understood to be financial services such as, savings, insurance, or money transfers provided, by microfinance for poor individuals or people living on low incomes. Thus, the main objective of this financing is to reduce poverty in 
general and also unemployment. This loan is therefore carried out by specialized agencies called microfinance institutions.

Therefore, microcredit can contribute and often contributes to poverty reduction by offering to the poor an opportunity to overcome any difficulties, without having to discard assets that are important for their survival. It can also make it possible to set up a profitable business, that is to say, it is able to generate income for the borrower and his family, but this will depend on how he makes this credit granted.

These structural difficulties of a social and political nature in Mozambique are observed in the growth of obstacles among low-income families in obtaining credits from traditional banks in order to practice income generation or wealth creation activities. However, in Mozambique there is still the notion that people with low economic power who want to start small businesses or develop entrepreneurship are not worthy of credit.

Therefore, PARPA II (2006: 115), in the pillar on Economic Development, poses one of the main challenges, reducing poverty in the country, and there is a need to modernize and expand the financial system, creating new instruments for regional coverage, especially taking into account the form and the need to develop microcredit and microfinance services integrated in the formal financial system in order to mitigate the difficulties of access to credit by the population with few resources.

In order to achieve these objectives, it is necessary to analyze the means by which the beneficial effects of access to microcredit can be enhanced in the generation of income for the poor. The problem to be addressed is not just the integration of these instruments into poverty reduction programs but also shows that if the poor have greater access to sustainable microfinance products and services, they can themselves escape the poverty to which they are immersed.

The problem that guides this research is: to what extent do microcredit activities boost the fight against poverty to sellers of the Xipamanine Market in Maputo City? To support this question, which is the guiding principle of this research, the hypothesis according to which the granting of microcredit to borrowers contributes to the improvement of their poverty, contributes in a way to realize how important is to grant credit to the people in need.

Qualitative, bibliographical, empirical verification and questionnaire interviews guided this research, which combine with the hermeneutic-reflexive approach to reach effectively the theoretical framework of activities aimed at reducing poverty to informal sellers in the Xipamanine Market in Maputo city.

Therefore, this article is divided into three parts, in addition to this introduction and conclusion. In the first one, the context of the emergence of microcredit and microfinance in general is presented in a well-founded way; then an approach of microfinance system and the Credit Cooperatives in Mozambique is taken and finally the research data are analyzed and interpreted.

\section{Context of the Emergence of Microcredit and Microfinance}

The literature that talks about microcredit agree with the idea that microcredit at its genesis arises as an agglutinating element that seeks to generate employment and income mainly for people without financial possibilities. The credit granting institutions, besides granting the credit to the formal entrepreneurs also guarantee the credit to those people who do not have pecuniary guarantee. In this perspective, credit cooperatives arise with the intention of encouraging those people who have some desire and / or idea to start a certain business or any economic activity.

Throughout the world, the experiences of borrowers lead to conclusion that, if credit is received in a serious and responsible way, with an effective business plan, it is possible to create employment and welfare for the poor, ensuring their economic and socio-cultural development.

The discussion of the international literature proves that "the idea of microcredit as a powerful tool in the fight against poverty has impact on the academic, political and international development, with greater attention being paid to microfinance institutions. Microcredit thus emerges as a promising alternative to take loans to microenterprises. In the early years of microcredit, it was believed that it would be a way to combat poverty and social exclusion over the years" [1].

In spite of these findings, it is verified that microcredit cooperatives arose from the need to establish a credit alternative for the population of the formal and informal sector, who, because of not having monetary guarantees, they do not access to the formal credit system. While at the same time making a measure of alleviation to the conditions of poverty in which they are immersed, guaranteeing them an occupation, a job and indeed a source of income generation [2].

According to Ruas et al. (2015), microcredit are financial intermediation services, in order to provide access to credit and strengthen less structured enterprises. Civil society institutions can carry out this activity by the public power or by means of partnerships between these agents, having the potential to enable the economic inclusion of millions of people who are not served by the traditional financial system.

Microcredit is a small-scale credit provided to disadvantaged people who do not have access to formal credit, and it dates back to its existence since the nineteenth century, as many countries have demonstrated experiences of granting small-scale values to the effective reach of their objectives and to reduce poverty.

The Consultative Group to Assist the Poor (CGAP), which is a global partnership, part of the World Bank, of more than 30 leading organizations seeking to improve financial inclusion, is dedicated to the development of innovative solutions through hands-on research and active engagement with financial service providers, policy makers and funders to allow for scaled approaches, so it is limited to defining Microfinances "provision of services to low-income people" [3]. 
Therefore, "the first known microfinance initiative occurred in southern Germany in 1846" [4]. Because of the cold that was felt in that country and that year, many farmers had to ask for loans sharks to boost their enterprises in order to improve their life situation.

Friedrich Wilhelm Raiffeinsen $(1818-1888)^{1}$, a pastor at that time, who noted the social and economic impacts of his credit cooperative, gave to farmers, wheat flour for the manufacture and sale of bread, thus generating working capital for the farmers. At that time, it created an association that grew and turned into a credit cooperative for the neediest populations.

Therefore, the other historical credit and microfinance took place in Canada in 1900 through a journalist from the Legislative Assembly of Québec where more than 12 friends collected monetary resources with an initial amount of 26.00 Canadian dollars to lend to disadvantaged, deprived persons in financial resources. The "reports say that this initiative was called Caisses Populaires, and today it has 5 million members divided into more than 1000 agencies" [4].

In 1953, Walter Krump, in the United States, created a credit cooperative within the factory with his own funds, where "every worker should be paid per month with a value of USD 1.00 in order to give the same value to those who needed the credit. Subsequently, the model created by Walter Krump was called the 'Help Fund"' [4].

Between the years of 1846 and 1976, there are several movements linked to the granting of credit, which occurred at that time as a tendency to become microcredit [5]. Along the same path, "the most internationally known microcredit experience has been developed in Bangladesh, one of the poorest countries in the world" [6].

Microcredit came about through non-governmental initiatives, but little by little, they were incorporated into the agendas of public power. The first such experiments in the world were developed by Muhammad Yunus in Bangladesh (1974) and by ACCION International, which since the 1960s has been active in Latin America [7].

Thus, the experience of granting credit spread throughout the world, and in 1976, the economist Muhamad Yunus (1940 $-)^{2}$, used this idea for the dissemination and popularization of microcredit. Therefore, Yunus in 1974, seeing the destruction of Bangladesh by natural disasters and famine, proposes to do research to analyze, after natural disasters, what people were used to their survival.

Because of his research, he finds that there was a misery in the population, and that the small entrepreneurs in the villages were 'hostages' of the moneylenders who demanded

\footnotetext{
1 Raiffeinsen, of German origin, is recognized around the world as the creator and founder in 1864 of the so-called first rural credit cooperative in Germany. He took this initiative, with the aim of alleviating the great economic need of the population in terms of access to credit. Two years later, he created a 'circle of loans', thus launching the roots for the organization of the Raiffeisen cooperatives. 2 Nobel Peace Prize in 2006 for the founding of the Grameen Bank and the creation of microcredit (small loans for poor people). He is known as the father of Microcredit, on the proposition that we should not seek, but rather create our own employment.
}

these, very high values, when they made loans. It was from these facts that Yunus, lent to a group of 27 people, a value of USD 42.00. Therefore, by borrowing this amount, he created the foundation of Grameen Bank ${ }^{3}$ in 1978 or Bank Village, which gives value to low-income and deprived people in Bangladesh.

It was with this experience that Yunus was able to prove that poor people deserve credit, since they can repay the value of their loan that channels them to their production activities. Independent studies, therefore, prove that "in 10 years, Grameen Bank has taken more than half of the people out of poverty, and this has raised the country to one third above the poverty line" [8].

Yunus was convinced that "all human beings are potential entrepreneurs. We all have an innate capacity, which I call survivability. Like food, credit is a human right. Microcredit is not a gift, it is a loan" [9].

The Grameen Bank focuses on the proposition that the poor have skills that remain unusable or underutilized, which is why Yunus claimed: "It is not the lack of aptitude that makes the poor people poor's," says Muhammad Yunus, "Grameen Bank believes that poverty is not created by the poor, it is created by institutions and by policies pursued by society. I firmly believe that giving unemployment benefits is not the best way to tackle the problem of the poor. For me, it is about ignoring their problems and letting them rot" [8].

Therefore, the poor in good health do not want or need charity: "Allowance only increases their misery, deprives them of initiative and, more important, of self-esteem. Releasing energy and creativity in each human being is the response to poverty" [9].

According to Yunus (2006) being poor is not a condition, but a situation, so the poor are poor because they cannot retain the product of their labor, which will benefit those who own and control the means of production. The return of the credit granted to people only works when they have collateral.

In this way, Yunus states that "the poor strive more than the rich to repay their loans, our clients do not need to prove that they have much money for savings or that they are rich; on the contrary, they need to prove how poor they are and how few their economies are" [8].

Many regions of the world are still in the trap of the vicious circle of poverty and underdevelopment. When analyzing the performance of the system it can be observed that there are three circles - cultural, demographic and economic-financial that are interconnected and feed each other [9].

Studies exist that refer that poverty is to feel that you do not have enough to go on, to do what you should do. In this sense, this perception is called subjective poverty, and microcredit can be a means to reduce poverty. It is for this reason that informal credit systems exist on a small scale, although they exist in many parts of the world, especially in

3 This bank was based on mutualism, trust, participation and creativity, lending to the poorest of the poor, especially women. 
rural areas.

Therefore, "the reduction and elimination of poverty has been considered as the main objective of development policies in the medium and long term. However, when one speaks of poverty, different ideas about its meaning have often emerged. This fact results from poverty being a complex phenomenon, multidimensional and with diverse characteristics" [11]. In this sense, the person is considered poor or rich in accordance with the monetary gains he has and also through consumption per capita.

Informal credit granting systems provide to the poor the access to locally generated savings and function as a certain monetary guarantee when inflation exists, thus creating some credit unions that guarantee credit to those who do not have access to formal credit and / or traditional.

The percentage of the Mozambican population living below the poverty line is $54 \%$ (according to a household income survey conducted between 2002 and 2003), although it has declined in recent years - was 69\% between 1996 and 1997 [12], and nowadays is about $72 \%$.

Murdoch's (2004) studies provide the impression that in Mozambique the informal sector developed after the Rome General Peace Agreement (1992), both in urban and rural areas. In this sense, although there are no reliable statistics on this subject, however, it is estimated that $85 \%$ of the active population work in the informal sector, $59 \%$ of which is made up of women.

As an example, the demand for credit among the most eminent markets in Maputo City estimates that, with a sample of 11,684 people, it was shown that only $10 \%$ of informal sellers had taken out a loan, $78 \%$ of which in a microfinance. On these, $85 \%$ did not use any banking services; $32 \%$ had never heard of microcredit; and $27 \%$ resorted to "Xitique" [13].

From its origin and in accordance with Casimiro and Neves de Souto (2010: 26), Xitique, means, Savings. The practice of Xitique in Mozambique is based on very simple forms, the process usually starts from a group of friends who come together, fix the amount of the contribution of each member and the frequency of the meetings for accountability and revolving distribution of savings, for each of them.

Funds circulate among their members and the collection and distribution function as a rule based on trust and empathy, while requiring each member of the group to make savings of a predetermined amount and within the periodicity previously defined for the payment of its quota. The distribution of savings among group members is made periodically and rotationally.

However, the credit (Xitique) can be in kind of a good or an animal, or in monetary value, depending on the purpose required by the constituent group and also the combination between them. Generally, Xitique's constituencies are in the number ranging from 4 to 10 people, among friends and family, and funds are raised in savings and granted to members individually and / or by two people depending on the number of constituents, where each member has his turn to receive.
According to Cunha (2011), the objective of xitique is the acquisition of goods, products and services that would otherwise not be accessible to a certain group of people due to the scarcity of money in which they live. However, what is considered central to xitique's analysis is that it is a practice that goes beyond a strategy for the survival of impoverished people, because it has extra-economic objectives and contributes to social cohesion, control of existing resources, identity and affirmation.

Another frequent microfinance service is the moneylenders, "who grant individual credit in securities. The guarantees that are most frequently used are the good reputation of the borrower, pre-dated checks and personal possessions and high interest rates are paid monthly" [14].

According to Psico (2010) in the same path of microfinance services, there is the family fund where each family is obliged to contribute monthly an amount to a common account that can be used for a common purpose, ranging from sickness up to university fees.

In general, xitique consists of a group of people, made up of friends, colleagues or family members, who stipulate an amount of contribution as well as the periodicity of meetings to render accounts, rotating distribution of the saved for each one of the people involved in the group and fraternization. In Taniguti (2012) perspective, It also provides the creation or strengthening of an intra-group sociability, revealing aspects such as solidarity, trust, commitment, identity, strategies to overcome risk and uncertainty, status, power, among others.

Granting credit to low income people is one way to reduce poverty rates, especially in the third world countries. These populations are those who do not have access to traditional credit services in order to raise and / or start some economic activity.

Hence, the granting of microcredit to the most deprived persons is part of the activities that occur in the scope of microfinance, and is related to the economic activity that is girdled in the provision of financial services by microcredit institutions, such as banks, financial institutions, credit unions, non-governmental organizations, etc.

These institutions have the purpose of guaranteeing the supply of credit to individuals and companies with low income and excluded from the traditional financial system, that is, they do not have capacities in access to credit offered by banks, regardless of their productive activity.

Nowadays "the World Bank in connection with several Non-Governmental Organizations, including those that form international cooperation from states and are privately owned, have encouraged the creation of a microfinance market, as part of anti-poverty policies around the world" [15].

In February 1997, the Global Microcredit Conference, organized under the auspices of the World Bank, was held in Washington. Representatives of government agencies, development agencies, NGOs and financial institutions from around the world were present. For these institutions, credit is considered as one of the central instruments for fighting poverty, especially for the most deprived, and it opens up 
opportunities to provide the poor with other business-related financial services that they wish to develop.

According to Buchmann \& Neri (2008) and Psico (2010), credit does not create employment opportunities in itself, but rather allows good business opportunities arising from the granting of microcredit to be used. In this sense, a society without credit is a society of limited opportunities, where lucrative projects do not leave the paper, therefore, microcredit is fundamental because it is considered as an instrument that helps the populations with less possibilities, to take advantage of the opportunities that appear in their lives so as to generate sufficient income to change their living conditions, thereby boosting the local economy and thus reducing poverty.

Therefore, microcredit brings many benefits, since, in addition to helping the borrower himself, it also creates jobs for relatives, neighbors, and others. Psico (2010) warns credit institutions as well as borrowers that if credit is not applied in a good way it may not have the desired effects if it is granted to extremely poor families with no effective business plan, which in addition to food and other deficiencies may not have opportunities for self-employment (lack of opportunities to apply for credit, lack of infrastructure, lack of market), leaving no other way for them to consume the value of the loan, not being able to return.

In this sense, this warning competes for the realization that, the granting of credit has a complexity in its practice, so there is a need for a study of credit applications and a follow- up of their investment.

\section{The Microfinance System and the Credit Cooperatives in Mozambique}

The microfinance system in Mozambique "has its genesis in 1989, when the credit fund for urban enterprises was created this year in accordance with the World Bank's Urban Rehabilitation Program (PRU), which was in partnership with the Promotion Office of Employment (GPE). During this period this program provided some small-scale loans for some urban activities, and this fund came from the Popular Bank of Development (PBD), which it granted to this effect" [16].

According to Mozambique Bank data, the Mozambican financial system has 41 official credit institutions, most of which are commercial banks, which are, as shown in Figure 1, responsible for about $50 \%$ of transactions in the Mozambican credit market.

Table 1. Credit Institutions in Mozambique.

\begin{tabular}{ll}
\hline Financial Leasing Company & $3 \%$ \\
Credit Cooperatives & $20 \%$ \\
Investment Company & $2 \%$ \\
Microbancos & $22 \%$ \\
Commercial Banks & $46 \%$ \\
Electronic Currency Institutions & $7 \%$ \\
\hline
\end{tabular}

Source: Mozambique Bank (2017).

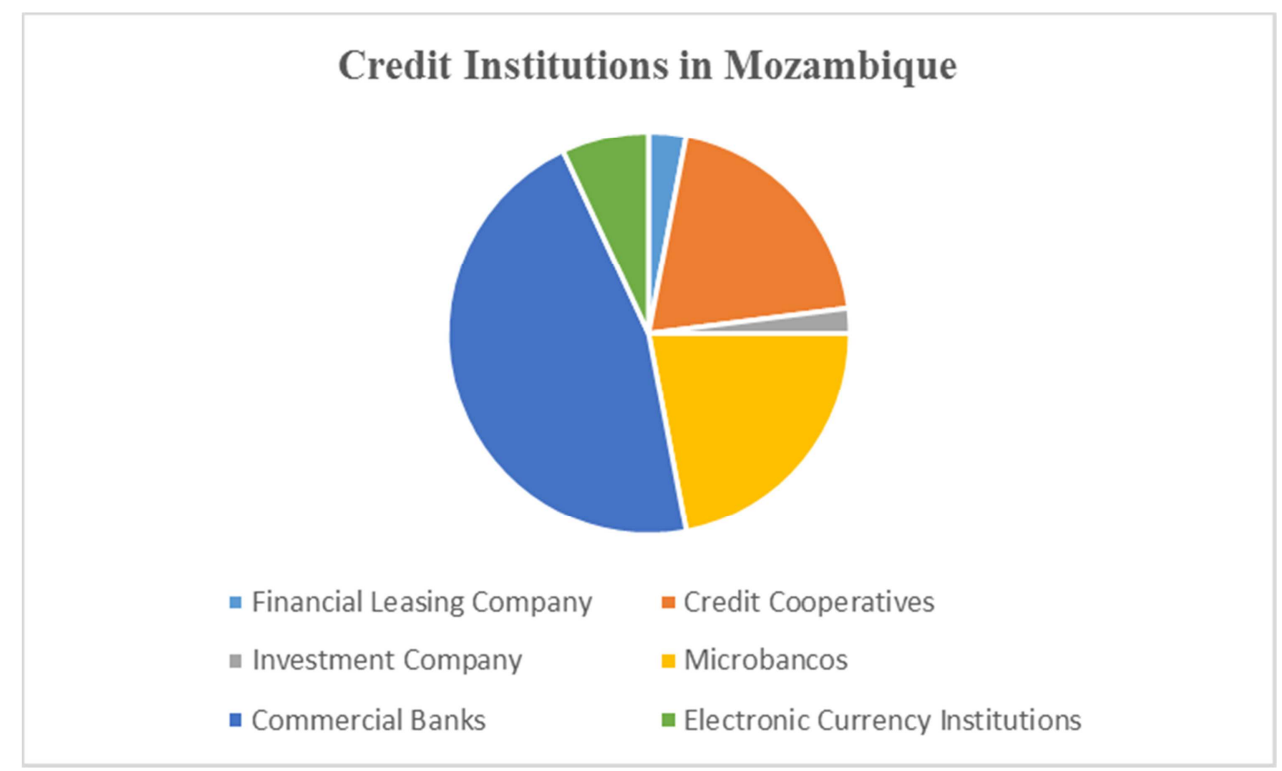

Figure 1. Credit Institutions in Mozambique.

The table and figure above clearly shows that the credit market is concentrated in the commercial banking sector, making it clear that alternative source of financing for households and businesses are limited. In addition, according to the results of the Mozambican banking sector survey conducted by KPMG (2016), the three largest commercial banks operating in Mozambique (Portuguese and South
African investments) account for about $80 \%$ of the 8 credit portfolios of the market.

However, with a view to the implementation of a microfinance system, studies show that this system became effective in practice in 1992, shortly after the signing of the General Peace Agreement (PGA). During this period, the granting of credit was mainly intended for former students 
who had just returned from the German Democratic Republic (GDR), who would have to start some employment and / or occupation activity with this fund.

Granted the credit to these students in 1993, World Relief came to Mozambique and started some credit granting primarily to poor people, especially women, who lived in rural areas. This grant of microcredit was made through some small community banks that emerged for this purpose.

From the perspective of Haffner \& Daniel, (2010: 85), as it was a first experience that Mozambique faced, a priori this initiative "generated some mistrust among the population, however, the results over time were impressive, reaching recovery almost double the amount allocated".

Between 1995 and 1996, the International Bank of Mozambique (IBM) and the Foundation for Community Development (FCD), through Swiss financing, had the idea of doing a project of granting credit to the needy through the creation of the Microcredit Bank (TCHUMA), considered as a cooperative dedicated to the concession of small credit.

After the emergence of this cooperative credit, the Institute of Recherche d'Aplications des Methodes de Dévelopment ${ }^{4}$ (IRAM), which in partnership with the Bank of de Mozambique (BM), in 1997, for the regions of Maputo and Chókwè, set up the Community Credit and Savings Bank (CCSB), which was considered to be a kind of community bank formed through the association of solidarity groups known as Community Boxes [17].

However, in 1998, due to the need to grant credit to the needy populations, the Mozambique Credit Society (SOCREMO) was created as the first microfinance program, of which the Mozambican Government financed $94 \%$ of the actions.

In the following year, 1999, a financial institution specialized in credit for the people of the field was created, which was designated Small Industry Support Office (SISOSARL). This year it started a lending mechanism for rural people, which until then was regarded as the only microfinance institution to lend.

More advanced studies show that SISO-SARL had many clients, among them, "the Credit and Savings Cooperative (TCHUMA), the Mozambique Credit Society (SOCREMO), the General Union of Cooperatives (GUC), the Community Credit Fund (CCF) and the associations of merchants and farmers. However, it was in this period that TCHUMA's activities were extended to the granting of credits to small entrepreneurs" [16].

Along to the same path, in 2000, according to Project Consult, the microbank of the global microfinance network, called PROCREDIT, was created. In the same perspective of the development of microcredit institutions in Mozambique, and according to Vletter (2006) quoted by Haffner \& Daniel (2010: 86), in 2004 "the Women's Development Fund (WDF) emerges through the Project Group Guarantee Loan and Savings (PGGLS) of the Non-Governmental Organization, and Save the Children based in the United States of

4 Research Institute of Applications of Methods of Development.
America".

According to the data provided by Mozambique Bank (2007) quoted by Haffner \& Daniel (2010: 86s), there is in Mozambique "some banks that are in the service of the microfinance industry, such as: General Savings and Credit, with the intends of granting credit and collect deposits from the public; Popular Finance Box, with the same function of granting credit for rural-centered activities; Savings Bank, and it can only grant credit within one year, and it is considered a non-profit or social solidarity institution and the Postal Savings Box, which also works as General Savings and credit Bank, but without granting credit. Here, the amount received as a result of the public's deposit can only be applied to investments, bonds and time deposits, or in similar operations" [18].

In another perspective, it may be noted that, although people at some point in their lives in the early 1990s did some microcredit activity, they only used a series of traditional and informal systems to acquire loans in order to get credit.

Therefore, these financial institutions, through the provision of financial services to their associates and / or poor, low-income population, make an important contribution to local development as well as to poverty reduction.

In Mozambique, as stated above, there are many credit unions, however for methodological reasons; we will choose some for the case of this study.

\subsection{The Credit and Savings Cooperative (TCHUMA)}

The main founders of the Credit and Savings Cooperative (TCHUMA) are the Community Development Foundation (CDF) and the Financial Participation Control and Management Company (FPCMC), each holding $49.9 \%$ of the social capital in 1996.

This cooperative came about effectively with the initiative of the president of Investment Commercial Bank (ICB), Magid Osman, at which in that time he intended to establish another institution for people who did not have access to traditional banks. At that time, he joined the Foundation for Community Development (FCD) and the Partnership for Control and Management of Participations, which in turn are the shareholders.

TCHUMA's general purpose is to offer microfinance services and other banking activities permitted by legislation in force in the country. TCHUMA offers two types of credit. The first is linked to economic activities ranging from $500.00 \mathrm{Mtn}^{5}$ to $60,000.00 \mathrm{Mtn}$, which are granted to people who already have a business with a minimum experience of 6 months. The term of the loan varies between 1 to 12 months. The single interest rate is $5 \%$ per month and the installments are monthly.

There are two types of loans, loans in solidarity groups (do not require real guarantees) and individual loans (they require

5 To get a clear idea, currently 1 US dollar corresponds to approximately 65,00 MTn. 
collateral made up of domestic assets). The other is for consumption and is intended for State employees, in particular teachers and education staff, and offers a maximum value of $100,000.00 \mathrm{Mtn}$ in terms of up to 24 months and interest rates ranging from 3 to $3.5 \%{ }^{6}$.

\subsection{The Mozambique Credit Society (SOCREMO)}

This microcredit bank was established in Maputo on May 26, 1998, and was designated as the Mozambique Credit Society. Its origin is a result of a long process in which the then Office for the Promotion of Employment (OPE) tended to become a social support project, and thus should create a credit institution that would provide microfinance services for those with low incomes and who did not have access to financial services in commercial banking.

Thus created, SOCREMO focused its efforts as a specialist in microfinance, granting a variety of financial products and services linked to meet the needs of micro, small and medium enterprises.

Anyone can have access to credit, but to do so, is need to have business that works for at least six months. For the credit to be approved, an application must be issued for the granting of credit, but the concession will depend on an evaluation of the business and the delivery of the necessary documents and information. The amount to be granted varies from 5,000 Mtn to 200,000 $\mathrm{Mtn}^{7}$ at an interest rate of $6 \%$.

\subsection{PROCREDIT Bank, Mozambique}

PROCREDIT bank was founded in 2000 by an alliance of international investors with a development orientation and offers excellent services to clients and a wide range of banking products, namely microcredit, savings and other services (national and international water, etc.).

It was initially founded under the name of New Bank by the shareholders of IBM, International Micro Investment (IMI), the International Finance Corporation (IFC), the Netherlands Development Finance Company (FMO) and the Fund for Development and Housing (FDH). As part of the restructuring of its shareholders in 2007, it changed its name to Mozambique PROCREDIT Bank. It was in the context of the change of name that it extended its services becoming a good provider of banking and macrofinancial services ${ }^{8}$.

PROCREDIT Bank aims to establish a new type of financial institution that responds to the needs of small and medium-sized enterprises in a socially responsible way. With a view to responding to the demand of microfinance services, PROCREDIT has expanded its business range to hard-toreach rural areas. Its credit portfolio is aimed at small entrepreneurs, small and medium-sized enterprises, and the

$6 \mathrm{http}: / /$ www.financingmozambique.com/?_target_=institution\&id=58. Consulted on 4th march 2019).

7 (http://www.socremo.com/index.php/pt/quem-somos/historia-do-socremo. Consulted on 3rd march 2019).

8 (http://www.macauhub.com.mo/pt/2019/03/03/grupo-ecobank-transnational-anegociar-compra-do-banco-procredit-de-mocambique/. Consulted on 3rd march de 2019). low-income population.

In order to have credit at PROCREDIT Bank, a person must already have a business that has been working for at least 6 months, so that it guarantees a loyalty of the return of the same. The guarantor of this bank does a screening of the products sold or the business practiced by the borrower only after it grants the credit.

Most of the credit guarantee is for the economic activities ranging from $1,000.00 \mathrm{Mtn}$ to $200,000.00 \mathrm{Mtn}$, value granted to micro entrepreneurial borrowers with a minimum of 6 months' experience in the business. The term of the loan varies between 2 and 24 months. The single interest rate is $6 \%$ per month. The requirement to have a business that has been in place for at least six months is also closely linked with the experience one may have, for it is necessary to know whether the person is capable of managing his own money before being granted the money for her to manage and this aspect is common to all microcredit banks.

It was from May 2014 that PROCREDIT Bank sold more than $96 \%$ of its shares to ECOBANK, being a bank that integrates the clients of the then PROCREDIT Bank into The Pan African Banc (ECOBANK).

\section{Analysis and Interpretation of Research Data}

The study was carried out as mentioned in the Xipamanine Market which is located on Irmãos Robby Avenue in Maputo City and is considered one of the largest informal markets in the city, where the products sold there, its variety as well as diversity of buyers and sellers that go there, exceed all the pretense and idea of the level of investments made.

However, the diversity of product offerings and the movement of people in recent years has been growing dramatically. Its initial formation dates back to colonial times, for reasons and processes identical to those that led to the creation of other informal markets in the City and Province of Maputo. Xipamanine market grew explosively in a few years and became a marketplace with more than 10,000 vendors, both wholesalers and retailers, both formal and informal.

Thus, the Xipamanine Market is indeed a semi-collective transport terminal, with connections to all points of the city and the province of Maputo, thus giving to this place a great centrality and place of great population size.

Although this market has all the physical characteristics of a market with a provisional status, when evaluating existing buildings, there are some doubts about its real status as a market. Its size and organization, like other markets in Maputo City, is a mess, seeming to be an improvisation for those who want to do some serious business activity.

There is a government structure within the market that represents the relationship between the sellers and the external public, as well as a police station that responds to any diatribes that may arise within the market.

There are, therefore, a number of associations within the 
market, which make a link between the municipalities and improve the market situation in terms of minimum infrastructure such as piped water, electricity and public toilets financed by traders as well as by private managers.

The Xipamanine Market is indeed protected by the community security forces organized by the existing associations. All formal and / or informal vendors pay a daily fee of $20.00 \mathrm{mtn}$ to ensure market safety. In the field study we interviewed 80 informal sellers divided into men and women, schooled or not, and we used a questionnaire with closed answers, using a simple random probabilistic sample, and the data were sent to the SPSS 21.0 software package that generated the tables automatically.

Table 2. Location of the Monetization of the Requested Value.

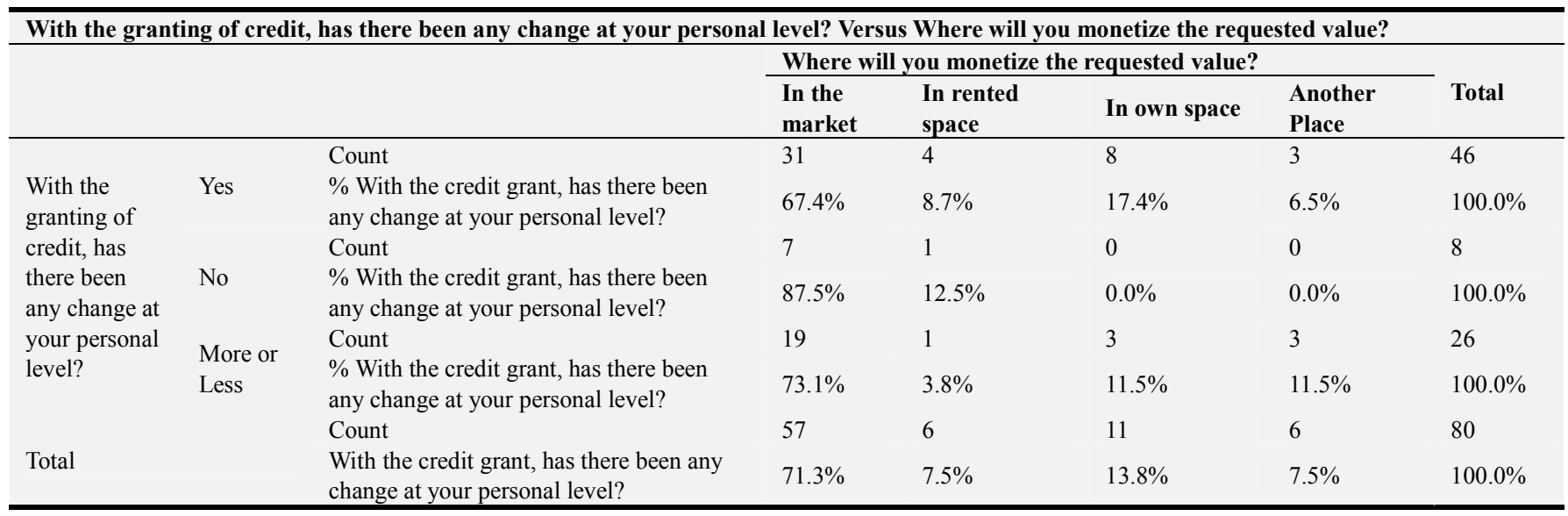

Source: Research Data.

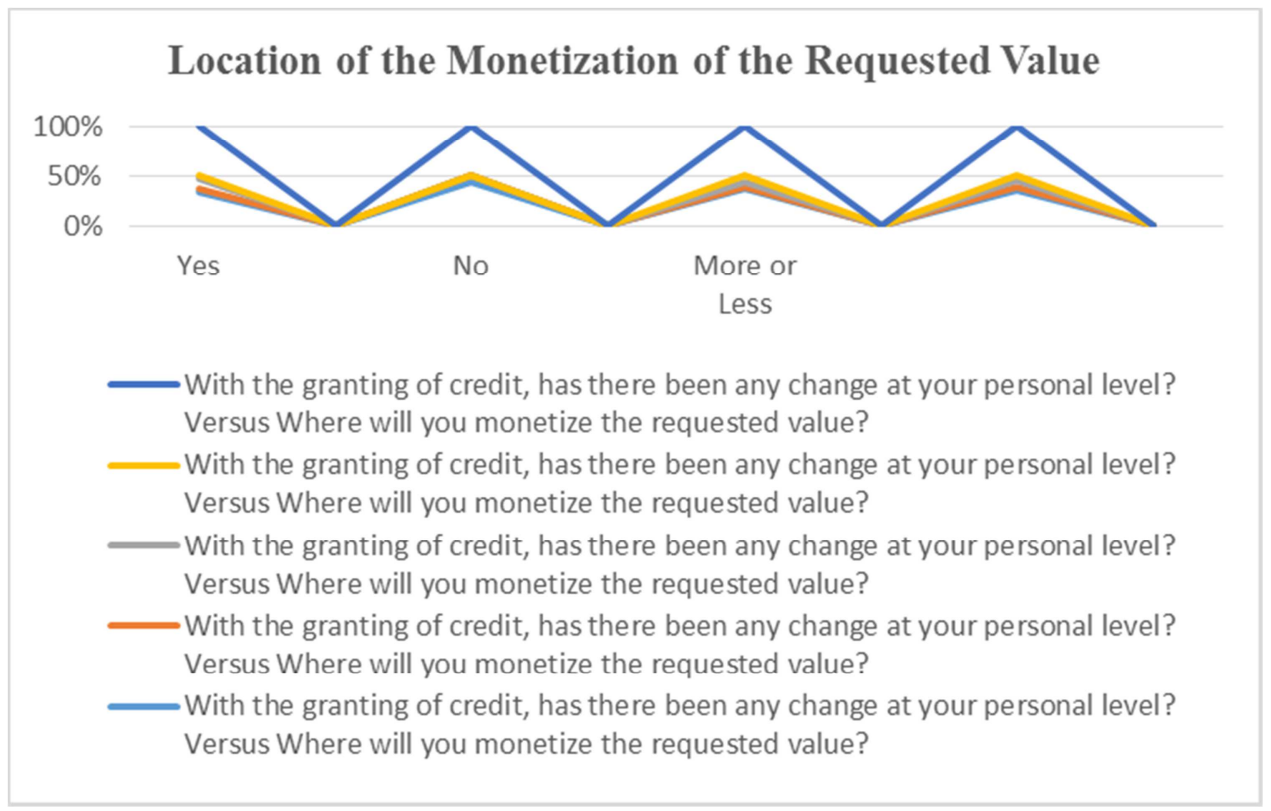

Figure 2. Location of the Monetization of the Requested Value.

According to the data in the table and figure above, the results show that, in an average of 80 respondents, with regard to the question of where the value requested will be profitable in the bank, the data show that, 57 respondents corresponding to $71.3 \%$ stated that will monetize the amount requested in the bank, in the market. They are followed by $13.8 \%$ of those who answered that they will be able to monetize the requested amount in their own space and finally followed by a percentage equality of $7.5 \%$ both of those who said they would monetize in rented space as those who responded that would monetize it elsewhere. According to these data, an absolute majority of $71.3 \%$ stated that it would monetize the amount requested in the bank, in the market.

By cross-checking these data with the category that, after the value has been allocated, has there been any change at your personal level, the data show that of an average of 46 respondents stated that there was in fact a change at the personal level, 31 of which correspond to $67,4 \%$ said in fact that it will monetize the amount requested in the market. Respondents who stated that they would allocate the amount requested in their own space correspond to $17.4 \%$ and are followed by $8.7 \%$ average percentage that corresponds to the 
respondents who stated that after receiving the amount, they will monetize in a rented space and finally a minority of $6.5 \%$ answered that it will monetize the amount requested elsewhere.

Regarding respondents who stated categorically that after receiving the credit there was no change at the individual level, an average of 8 respondents, 7 of them, corresponding to a percentage of $87.5 \%$ stated that they will allocate the amount requested in the market, followed by a $12.5 \%$ average percentage that stated that it will monetize the amount allocated in a rented space. There was no respondent with regard to the allocation of value both in the own space and in elsewhere.
In this sense, in an average of 26 respondents who stated that there was a small change at personal level after receiving the credit, an absolute majority of $73.1 \%$ stated that it will monetize the amount requested in the market, followed by a mean percentage of $11,5 \%$ of those who said they will monetize the requested amount in their own space and elsewhere. Only, a minority of $3.8 \%$ stated that it would monetize the value in its own space.

After analyzing these data, it was concluded that the absolute majority of $71.3 \%$ of respondents would monetize the amount requested in the market, giving a recommendation to the bank to grant credit to those who wish to monetize the amount allocated in the market.

Table 3. Credit Granting Institution.

\begin{tabular}{|c|c|c|c|c|c|c|c|}
\hline \multicolumn{8}{|c|}{ With the granting of credit, has there been any change at your personal level? Versus Which institution did you receive the credit? } \\
\hline & & & \multicolumn{5}{|c|}{ Which institution did you receive the credit? } \\
\hline & & & $\begin{array}{l}\text { PROCREDI } \\
\text { T Bank } \\
\end{array}$ & $\begin{array}{l}\text { TCHUMA } \\
\text { Bank }\end{array}$ & $\begin{array}{l}\text { SOCREMO } \\
\text { Bank }\end{array}$ & Others & Total \\
\hline \multirow{5}{*}{$\begin{array}{l}\text { With the } \\
\text { granting of } \\
\text { credit, has } \\
\text { there been } \\
\text { any change at } \\
\text { your personal } \\
\text { level? }\end{array}$} & \multirow[b]{2}{*}{ Yes } & Count & 15 & 2 & 8 & 21 & 46 \\
\hline & & $\begin{array}{l}\% \text { With the granting of credit, has there been } \\
\text { any change at your personal level? }\end{array}$ & $32.6 \%$ & $4.3 \%$ & $17.4 \%$ & $45.7 \%$ & $100.0 \%$ \\
\hline & No & Count & 4 & 0 & 2 & 2 & 8 \\
\hline & \multirow{2}{*}{$\begin{array}{l}\text { More } \\
\text { or Less }\end{array}$} & Count & 5 & 3 & 3 & 15 & 26 \\
\hline & & $\begin{array}{l}\% \text { With the granting of credit, has there been } \\
\text { any change at your personal level? }\end{array}$ & $19.2 \%$ & $11.5 \%$ & $11.5 \%$ & $57.7 \%$ & $100.0 \%$ \\
\hline \multirow[b]{2}{*}{ Total } & & Count & 24 & 5 & 13 & 38 & 80 \\
\hline & & $\begin{array}{l}\% \text { With the granting of credit, has there been } \\
\text { any change at your personal level? }\end{array}$ & $30.0 \%$ & $6.3 \%$ & $16.3 \%$ & $47.5 \%$ & $100.0 \%$ \\
\hline
\end{tabular}

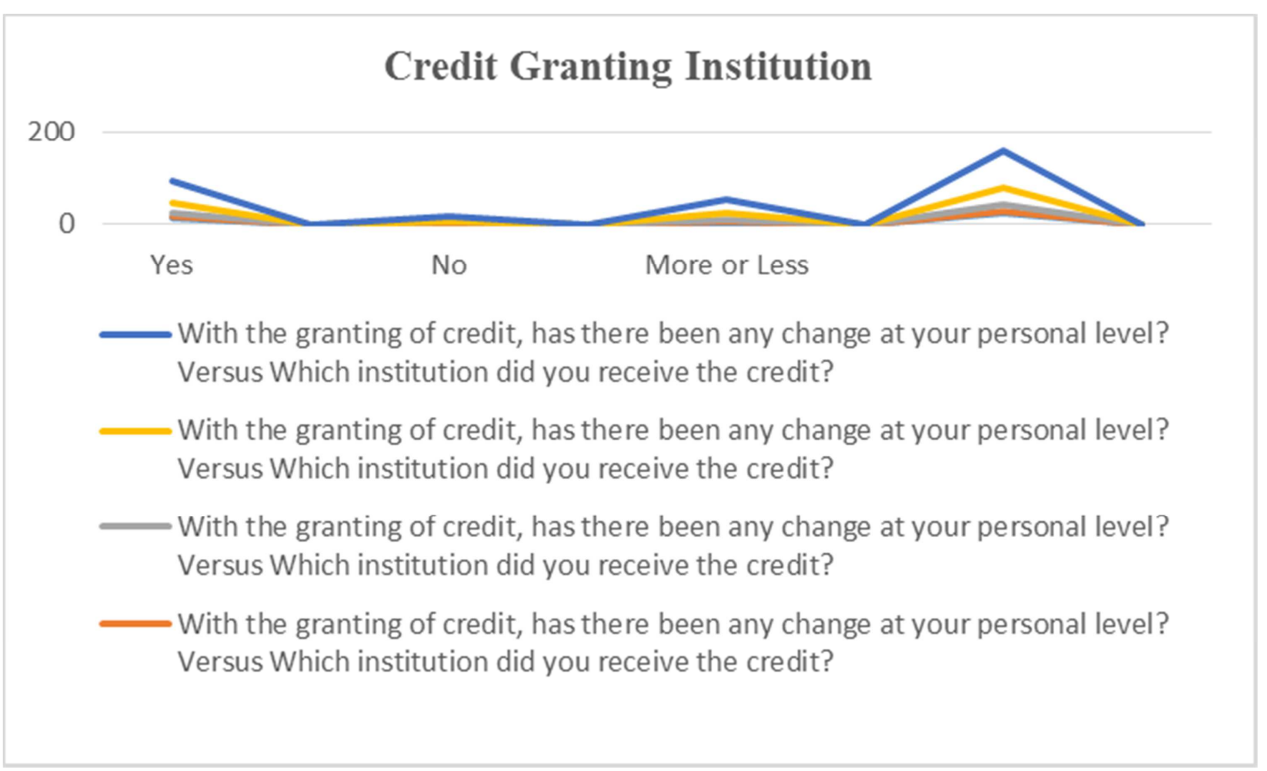

Figure 3. Credit Granting Institution.

The table and figure above shows the data on the institution where the borrowers used to have a credit, and the data show that out of 80 respondents, 38 of these corresponded to $47.5 \%$ said that they turned to other unspecified institutions, $30 \%$ of them to the PROCREDIT Bank. Of the same respondents, SOCREMO Bank had financed $16.3 \%$, and a minority of $6.3 \%$ had recourse to TCHUMA to obtain financing. With these data, it is noted that the absolute majority of $47.5 \%$ used other unspecified sources of financing.

By crossing this data with the constant variable of whether or not there was any change at the personal level after receiving the credit, the data show that, in a universe of 46 respondents who affirmed positively, the data show that 21 of them correspond to $45.7 \%$ said they received credit in other credit institutions. $32.6 \%$ stated that they received credit at PROCREDIT Bank; $17.4 \%$ of them received financing from Banco SOCREMO and, 
finally, $4.3 \%$ will have resorted to TCHUMA Bank to obtain their financing source. With these data, it is noted that the absolute majority of $45.7 \%$ to obtain their source of funding had to resort to other credit institutions.

However, with regard to the respondents who said that the fact that they received credit did not change in their lives, an average of 8 respondents, 4 of them, corresponding to $50 \%$ answered that they had as their source of funding the Bank PROCREDIT, and there was an absolute equality of $25 \%$, which stated that they had as source of financing both in the SOCREMO Bank and in other credit financing institutions. There was no respondent when referring to the TCHUMA bank.
For respondents who said that having received credit at the bank made a small change in their lives, the data show that an average of 26 respondents, 15 of which corresponded to $57.7 \%$, responded that they received their credit from other institutions of credit, $19.2 \%$ stated that they received their funding from Banco PROCREDIT, and there was a percentage equality of $11.5 \%$ that they claimed to have received credit both at TCHUMA and SOCREMO Banks respectively.

According to these data, it is noted that the absolute majority of $47.5 \%$ used other sources of funding and / or other banks to have the credit.

Table 4. Initiative to Request Credit.

\begin{tabular}{|c|c|c|c|c|c|c|}
\hline \multicolumn{7}{|c|}{ With the granting of credit, has there been any change at your personal level? Versus Why did you have the initiative to request Microcredit? } \\
\hline & & & \multicolumn{3}{|c|}{ Why did you have the initiative to request Microcredit? } & \multirow{2}{*}{ Total } \\
\hline & & & Expand the business & Recover the business & Other & \\
\hline \multirow{6}{*}{$\begin{array}{l}\text { With the } \\
\text { granting of } \\
\text { credit, has } \\
\text { there been } \\
\text { any change at } \\
\text { your personal } \\
\text { level? }\end{array}$} & & Count & 34 & 6 & 6 & 46 \\
\hline & Yes & $\begin{array}{l}\% \text { With the granting of credit, has there been } \\
\text { any change at your personal level? }\end{array}$ & $73.9 \%$ & $13.0 \%$ & $13.0 \%$ & $100.0 \%$ \\
\hline & & Count & 5 & 2 & 1 & 8 \\
\hline & No & $\begin{array}{l}\% \text { With the granting of credit, has there been } \\
\text { any change at your personal level? }\end{array}$ & $62.5 \%$ & $25.0 \%$ & $12.5 \%$ & $100.0 \%$ \\
\hline & & Count & 17 & 6 & 3 & 26 \\
\hline & Less & $\begin{array}{l}\% \text { With the granting of credit, has there been } \\
\text { any change at your personal level? }\end{array}$ & $65.4 \%$ & $23.1 \%$ & $11.5 \%$ & $100.0 \%$ \\
\hline \multirow[b]{2}{*}{ Total } & & Count & 56 & 14 & 10 & 80 \\
\hline & & $\begin{array}{l}\% \text { With the granting of credit, has there been } \\
\text { any change at your personal level? }\end{array}$ & $70.0 \%$ & $17.5 \%$ & $12.5 \%$ & $100.0 \%$ \\
\hline
\end{tabular}

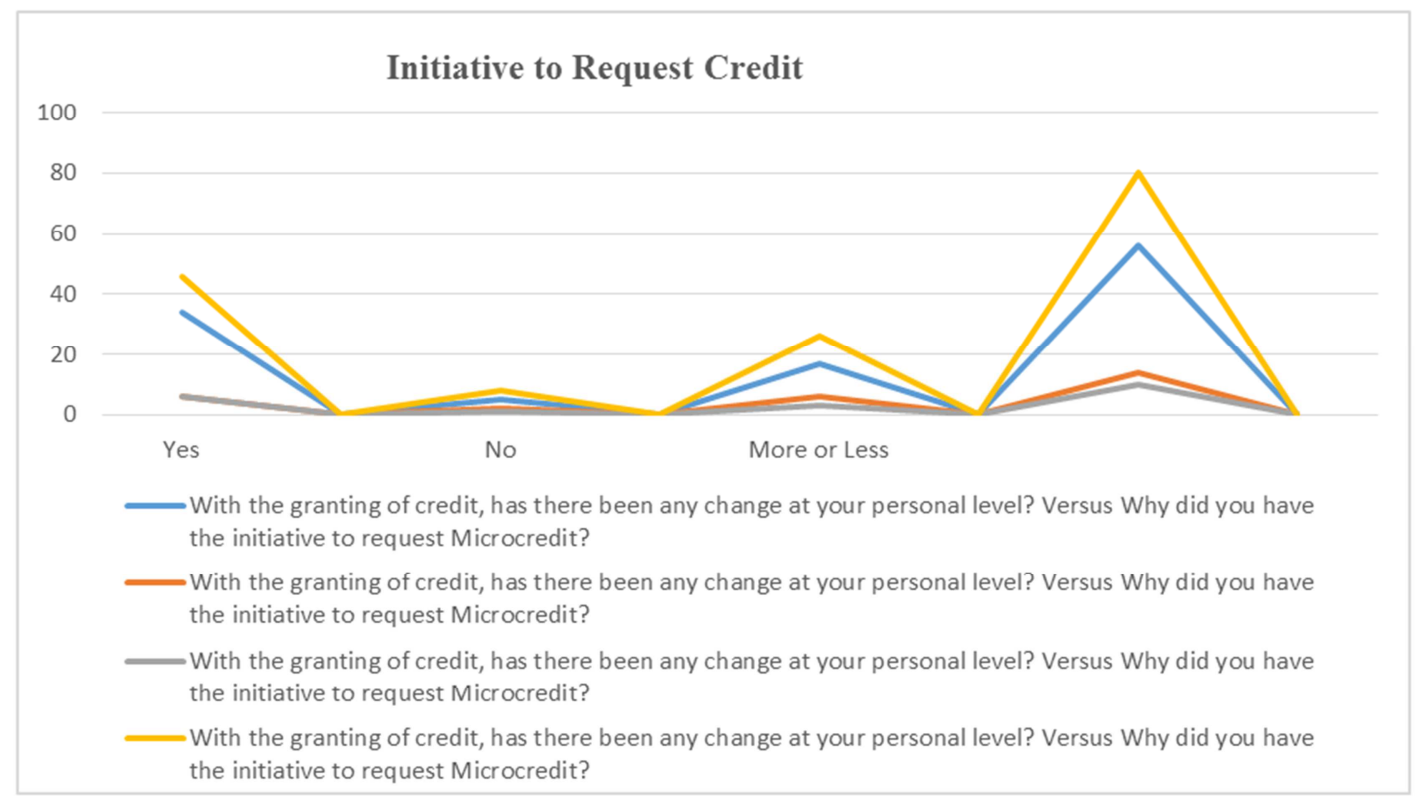

Figure 4. Initiative to Request Credit.

The data in this table and figure shows the question of the initiative, which led the respondents to ask for microcredit, and according to these data, it is verified that of the 80 respondents, 56 of them corresponding to $70 \%$ stated that they had the initiative to request microcredit to extend the business. $17.5 \%$ said that he approached the bank to ask for credit due to the recovery of his business and finally a group of $12.5 \%$ who said that they turned to the bank to ask for credit for other reasons.

Crossing this variable with that of whether or not the credit granting was a change at the individual level, the data in this table show that, in a universe of 46 respondents who answered that the fact that they had actually received the credit occurred personal change at the personal level, the data shows that 34 of these correspond to $73.9 \%$, and stated that they asked to the bank for financing in order to expand its 
business, with a percentage equality of $13 \%$ both of those who said they wanted to recover their business as of those who said they had other initiatives.

According to the data from those who stated that, the fact that they went to the bank to ask for credit did not result in any change, the data shows that of the 8 respondents, 5 of them corresponding to $62.5 \%$ stated that they went to the bank to request credit for the purpose to expand their business, and $25 \%$ said they went to the bank to ask for financing to recover their business and $12.5 \%$ went to the bank to ask for funding for various reasons.

The results of those who stated that the fact that they went to the bank changed their initial situation, an average of 26 respondents, 17 of these correspond to $65.4 \%$ said they went to the bank to ask for credit to expand their business, $23.1 \%$ said that they wanted to recover their business and, finally, an average percentage of $11.5 \%$ stated that they went to the bank with other interests.

With these data, it can be inferred that the absolute majority of $70 \%$ went to the bank in order to expand their business by recommending that credit managers must give credit, especially to borrowers who already have a business and who wish to only expand it.

Table 5. Evidence of Change or Not at Personal Level.

\begin{tabular}{|c|c|c|c|c|c|}
\hline \multicolumn{6}{|c|}{ With the granting of credit, has there been any change at your personal level? } \\
\hline & & Frequency & Percent & Valid Percent & Cumulative Percent \\
\hline \multirow{4}{*}{ Valid } & Yes & 46 & 57.5 & 57.5 & 57.5 \\
\hline & No & 8 & 10.0 & 10.0 & 67.5 \\
\hline & More or Less & 26 & 32.5 & 32.5 & 100.0 \\
\hline & Total & 80 & 100.0 & 100.0 & \\
\hline
\end{tabular}

\section{With the granting of credit, has there been any change at} your personal level?

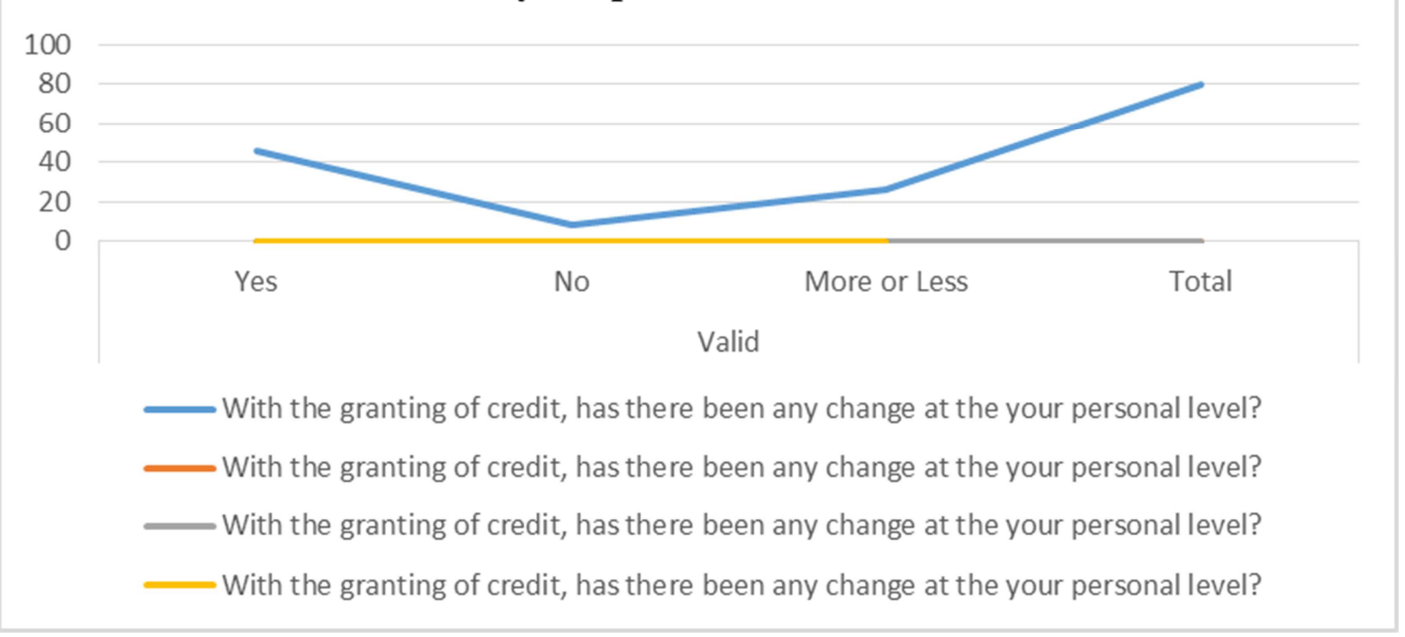

Figure 5. Evidence of Change or Not at Personal Level.

This is a summary table and figure on the granting of microcredit by borrowers, and asks whether after granting credit there has been some change at the personal level, and it shows that of the 80 borrowers surveyed, an average of 8 respondents corresponding to $10 \%$ said that after the credit was granted there was no change at the personal level.

However, of the 46 that corresponded to $57.5 \%$, who said that a change occurred and that $26 \%$ corresponded to $32.5 \%$, who said that there was more or less a personal change, they account for $90 \%$ of the borrowers who have effectively affirmed that, after the credit has been granted, there has indeed been a change on a personal level.

Therefore, the central argument of this research is reiterated, which indicates that in about $90 \%$ of the interviewees it is noted that, in fact, whenever banks grant microcredit to borrowers and they manage it well, there is a change in their initial situation.

\section{Conclusion}

In the course of this article, we sought to analyze the Role of Microcredit Activities as an Instrument for Poverty Reduction, taking as a case study the Xipamanine Market of Maputo City. Regarding the objectives initially intended and in accordance with the results obtained in this research, we find that the people who adhere to the credit are mostly men aged between 30 and 39 years. However, these are individuals who mostly have the basic and secondary level of schooling; hence, the microcredit emerges as an alternative employment factor, due to the high level of unemployment, that Mozambique faces mainly in the juvenile layer.

Respondents in this research when they receive credit in microcredit banks invest in the business to improve the living conditions of their families, especially in health, education, food 
and family independence. Most of the borrowers surveyed already had some commercial activity and were granted loans to expand their business, and this is a fundamental aspect, since there is an increase in small businesses, thus increasing entrepreneurship.

Thus, microcredit would build a financial system in Mozambique with new characteristics that would make microcredit available mainly to people who do not have access to the traditional public or private financial system. The concession of credit to the sellers of the Xipamanine Market in Maputo City represents a growing and fundamental segment for the uprising of the national economy, since its productive activity is important for the country's GDP, in addition to the employability generated by the sector.

As regards the impact of the credit granted, it was found that the majority of respondents improved their initial situation, improved their home feeding situation, and they felt more comfortable and there was an improvement in the education of their descendants, often bought some goods that they did not own. However, the granting of credit also had a significant impact since the data shows that there have been some changes at the personal level, which largely represents a decrease in social exclusion.

With regard to the initial question of research, that is, to what extent microcredit activities boost the fight against poverty to sellers of the Xipamanine Market in Maputo City, it is concluded that microcredit is indeed a very important instrument in the fight against poverty and social exclusion, since credit is well managed and contributes to improving the socioeconomic conditions of people who do not have access to credit in traditional banks, especially the sellers of the Xipamanine Market in Maputo City.

Finally, this research should serve as a means of reflection for all borrowers, especially those with low incomes, that when the bank grants the credit, income generation is not automatic, but rather must start from his initiative in rendering the value granted and this aspect is further evidence that in about $90 \%$ of respondents of this research, in fact, whenever banks grant microcredit to borrowers and they manage it well, there is a change in their initial situation.

According to the data found in this research, for microcredit to be a means to reduce poverty, it is necessary for borrowers to use it to expand their business. However, if this is indeed the objective of the borrower, credit may contribute to reduce poverty in the sellers of the Xipamanine Market in Maputo City.

\section{References}

[1] FIRMINO, Teresa Nachau Fernandes (2016). Microcredit as a Tool for Generating Income for Microentrepreneurs: an analysis applied to the Portuguese case. Dissertation of the Master. Lusophone University of Humanities and Technologies, School of Economics and Organizations. Lisbon, p. 10.

[2] MUSSAGY, C. (2005). Microfinance in Mozambique. Impact of Microcredit on Poverty Reduction: The Case of Chókwè and Maputo. EMU. Thesis of Degree in Management. Maputo.
[3] CGAP. (2017). Frequently Asked Questions about Financial Inclusion. The Consultative Group to Assist the Poor (CGAP): http://www.cgap.org.

[4] MONZONI, M. P. N., (2008). Impact on Microcredit Income: An Empirical Research on the Generation of Income from Popular Solidary Credit in the Municipality of São Paulo. Thesis (PhD) School of Business Administration, Fundação Getúlio Vargas, São Paulo. p. $35 ; 37$

[5] GOLDMARK, L., et al. (2000). The Situation of Microfinance in Brazil. Preliminary version for the International Seminar BNDES Microfinance: BNDES-IDB Microfinance Project, Rio de Janeiro.

[6] BARONE, F. M.; LIMA, P. F.; DANTAS, V.; REZENDE, V. (2002). Introduction to Microcredit: Solidarity Community Council. Brasília. p. 13.

[7] REYMAN, Ana Elizabeth Neirão (2013). Public policies, social capital and microcredit: An analysis of the experiences of Brazil and Chile. In: DIAS, Jean Carlos. SIMÕES, Sandro Alex de Souza. Law, Public Policy and Development. Rio de Janeiro: Forensic; São Paulo: Method; Belém, Pará: CESUPA.

[8] YUNUS, M. (2006) The Banker of the Poor, 2nd edition, Ed. Ática, São Paulo. p. 40; 45.

[9] COUTINHO, A. \& SILVA, P. (2005). Microcredit in Portugal: A New Opportunity, Millennium BCP, Lisbon. p. 13.

[10] PEROSSA, M. e MARINO, E. (2014). Relationship between the Ascent of Microcredit and Financial Poverty Alleviation in Latin Scene. Global Business Magazine. (4th ed.). EUA: Institute for Business \& Finance Research.

[11] PSICO, J. A. T. (2010). Microfinance - a solution to fight against poverty? Editora Escolar. Lisbon. p. 41.

[12] ATHMER, G. \& HUNGUANA, H. (2004). «Poverty Outreach and Impact Assessment in Mozambique», Characteristics of the Microfinance Sector \& of the Three Institutions Involved in the Impact Assessment, Netherlands Platform for Microfinance, Netherland.

[13] MURDOCH, K. (2004). Study of the Demand for Credit in Markets in Maputo, Maputo.

[14] CHIDZERO, A., FRÖHLICH-LASSIMO, C., HUNGUANA, H.; CUEVAS, C. (1998). Study on microfinance in Mozambique. Bank of Mozambique and Ministry of Planning and Finance. University Press, UEM, Maputo. p. 171.

[15] KRAYCHETE, E. S. (2005). The World Bank and the Development of Microfinance in Countries of the Capitalist Periphery. Thesis of ( $\mathrm{PhD}$ in Administration) - School of Administration, Federal University of Bahia, Ondina. p. 22.

[16] VLETTER, F. (2006). The Microfinance Sector in Mozambique: Achievements, Perspectives and Challenges, Maputo. p. 85, 86.

[17] HAFFNER, J. A. H. \& DANIEL, M. M. (2010). Contextualization of the Microfinance Sector in Mozambique, Period 2000 to 2006, in the Scientific and University Journal of the Center for Policy Analysis of the FLSC, on Political Economy and Development. Eduardo Mondlane University, Maputo. p. 85.

[18] BANK OF MOZAMBIQUE (2007). Banking of the Economy: Extension of Financial Services to Rural Areas. Nampula: XXXI Advisory Board of the Banco de Mozambique. p. 86. 